\title{
Neuregulin Directly Decreases Voltage-Gated Sodium Current in Hippocampal ErbB4-Expressing Interneurons
}

\author{
Megan J. Janssen, ${ }^{\star}$ Elias Leiva-Salcedo, ${ }^{\star}$ and Andres Buonanno \\ Section on Molecular Neurobiology, Program in Developmental Neuroscience, Eunice Shriver Kennedy National Institute of Child Health and Human \\ Development, Bethesda, Maryland 20892
}

The Neuregulin 1 (NRG1)/ErbB4 signaling pathway has been genetically and functionally implicated in the etiology underlying schizophrenia, and in the regulation of glutamatergic pyramidal neuron function and plasticity. However, ErbB4 receptors are expressed in subpopulations of GABAergic interneurons, but not in hippocampal or cortical pyramidal neurons, indicating that NRG1 effects on principal neurons are indirect. Consistent with these findings, NRG1 effects on hippocampal long-term potentiation at CA1 pyramidal neuron synapses in slices are mediated indirectly by dopamine. Here we studied whether NRG/ErbB signaling directly regulates interneuron intrinsic excitability by pharmacologically isolating ErbB4-expressing neurons in rat dissociated hippocampal cultures, which lack dopaminergic innervation. We found that NRG1 acutely attenuates ErbB4expressing interneuron excitability by depolarizing the firing threshold; neurons treated with the pan-ErbB inhibitor PD158780 or negative for ErbB4 were unaffected. These effects of NRG1 are primarily attributable to decreased voltage-gated sodium channel activity, as current density was attenuated by $\sim 60 \%$. In stark contrast, NRG1 had minor effects on whole-cell potassium currents. Our data reveal the direct actions of NRG1 signaling in ErbB4-expressing interneurons, and offer novel insight into how NRG1/ ErbB4 signaling can impact hippocampal activity.

\section{Introduction}

The Neuregulin1 (NRG1)/ErbB4 signaling pathway is involved in several aspects of neurodevelopment (Mei and Xiong, 2008) and both genes are candidate contributors to susceptibility for schizophrenia (Harrison and Weinberger, 2005; Buonanno, 2010). Much of the existing literature identifies NRG1's functional role on hippocampal plasticity by measuring pyramidal neuron properties (Huang et al., 2000; Kwon et al., 2005; Bjarnadottir et al., 2007). However, the ErbB4 receptor is not expressed by excitatory neurons, but rather by GABAergic interneurons (Vullhorst et al., 2009; Neddens et al., 2011). Several lines of evidence support the notion that NRG1-mediated effects on CA1 pyramidal neuron synaptic plasticity are indirect and require ErbB4 activation in interneurons. NRG1 acutely increases extracellular dopamine levels in the dorsal hippocampus and reverses long-term potentiation (LTP) by activating D4 receptors (Kwon et al., 2008), indicating a role for dopaminergic afferents to the hippocampus. Further, targeted ablation of ErbB4 in GABAergic parvalbumin-positive $(\mathrm{PV}+)$ interneurons blocks NRG1's ef-

Received March 20, 2012; revised Aug. 6, 2012; accepted Aug. 9, 2012.

Author contributions: E.L.-S. designed research;M.J.J. and E.L.-S. performed research;M.J.J. and E.L.-S. analyzed data; M.J.J. and A.B. wrote the paper.

M.J., E.L.-S., and A.B. were supported by the NICHD intramural research program. We thank Dr. Irina Karavanov for hippocampal cultures, and Drs. Stefano Vicini and Detlef Vullhorst for critical reading of the manuscript.

${ }^{*}$ M.J.J. and E.L.-S. contributed equally to this work.

Correspondence should be addressed to Dr. Andres Buonanno, Section on Molecular Neurobiology, Building 35, Room 2C-1000, 35 Lincoln Drive, National Institutes of Health, Bethesda, MD 20892-3714. E-mail: buonanno@mail.nih.gov.

DOI:10.1523/JNEUROSCI.1420-12.2012

Copyright $\odot 2012$ the authors $\quad 0270-6474 / 12 / 3213889-07 \$ 15.00 / 0$ fects on LTP in CA1 pyramidal neurons (Chen et al., 2010; Shamir et al., 2012), but selective ablation in excitatory neurons does not (Chen et al., 2010). Therefore, the effects of NRG1 on LTP induction/reversal requires intricate interactions between GABAergic and dopaminergic transmission at hippocampal networks (Buonanno, 2010).

Because ErbB4 is expressed in the somatodendritic region of GABAergic interneurons, it is important to investigate how NRG1 directly regulates the intrinsic excitability and firing properties of ErbB4-expressing (ErbB4+) interneurons. Modulation of action potential (AP) waveform and firing rates shape interneuron output, and voltage-gated sodium $\left(\mathrm{Na}_{\mathrm{v}}\right)$ channels regulate the activation and depolarizing phases of an AP (Bean, 2007), as well as spike frequency (Yu et al., 2006; Milescu et al., 2010b). Modulation of these currents affects AP threshold, and decreased $\mathrm{Na}^{+}$currents augment AP threshold and reduce neuronal excitability (Matzner and Devor, 1992). Voltage-gated potassium $\left(\mathrm{K}_{\mathrm{v}}\right)$ channels also modulate several aspects of neuronal excitability including firing rate and spike duration (Lawrence et al., 2006).

Because NRG1 mediates dopamine release in brain slices (Kwon et al., 2008), which can directly affect neuronal excitability (Govindaiah et al., 2010), it is difficult to study NRG1-mediated intrinsic effects in slices where afferent terminals express neuromodulators. Therefore, we have used dissociated hippocampal cultures that are devoid of extrinsic inputs, in combination with pharmacological blockade of synaptic glutamate and $\mathrm{GABA}_{\mathrm{A}}$ receptors, to study the acute effects of NRG1 on intrinsic, excitable properties of ErbB4+ interneurons. We sought to assess the most direct effects of NRG1 on ErbB4+ interneuron excitability to 
A

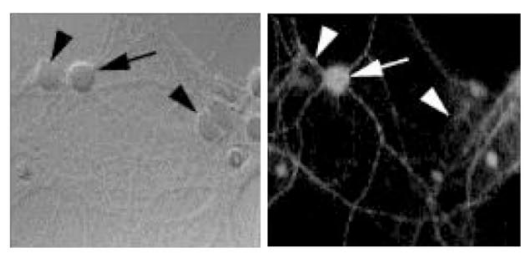

C

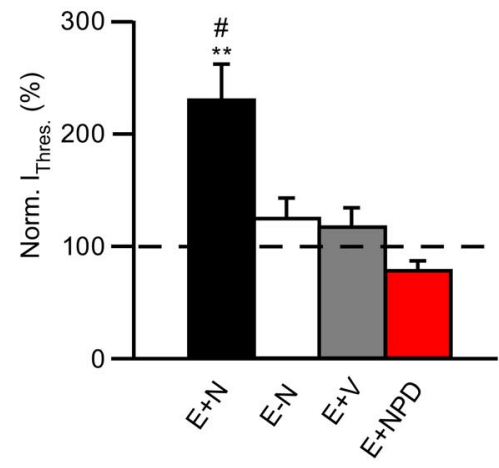

D

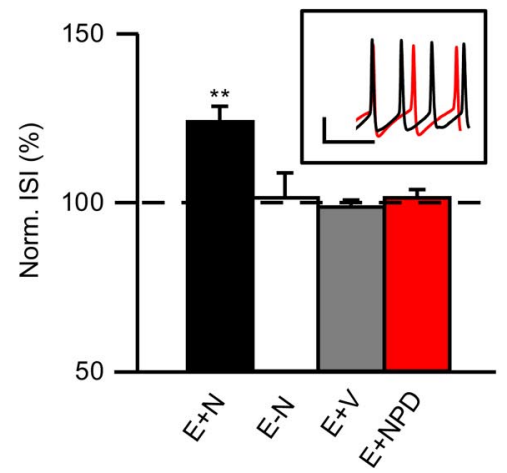

B
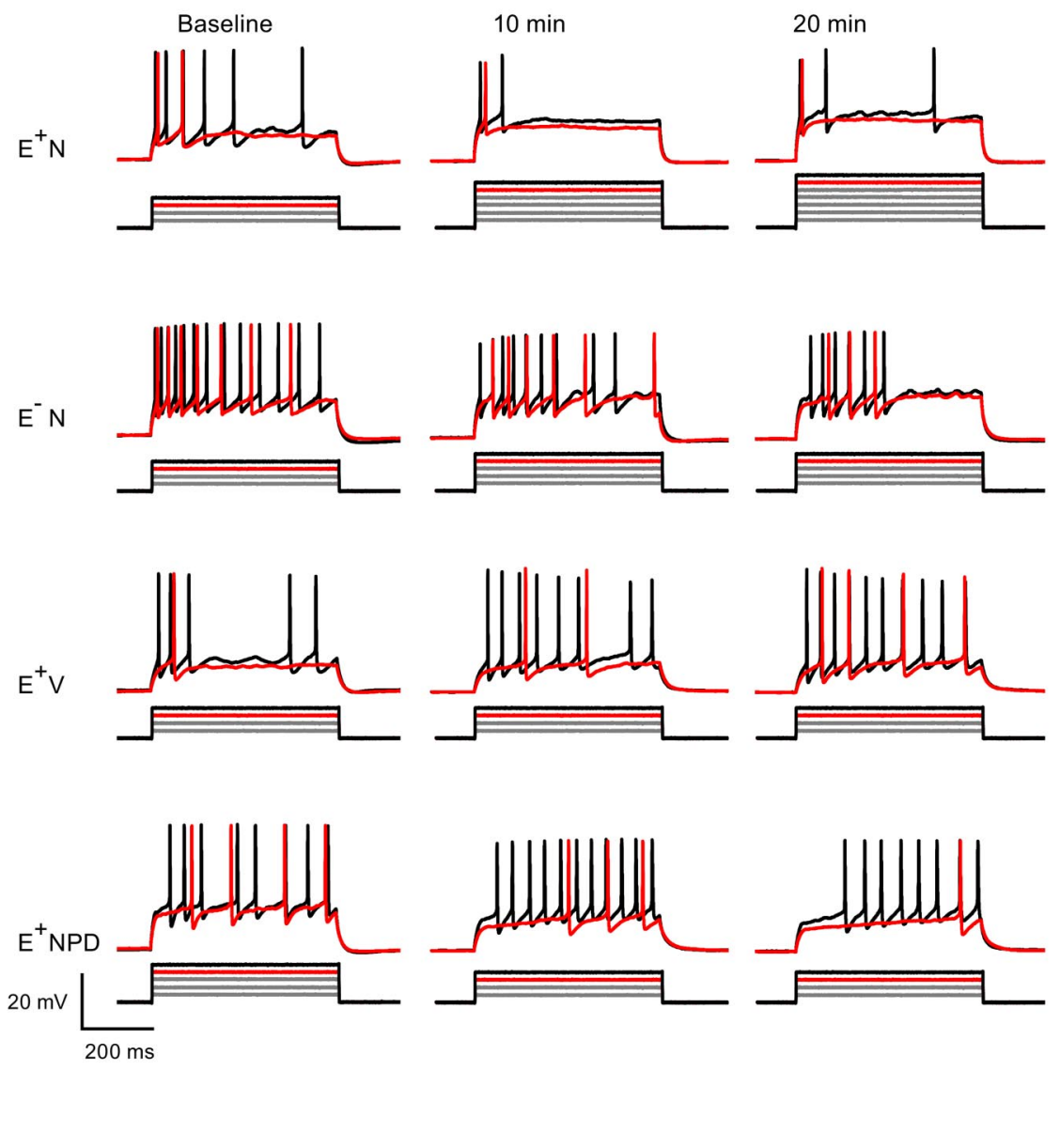

Figure 1. NRG1 decreases ErbB4+ neuron excitability. $\boldsymbol{A}$, Neurons live-labeled with mAb77 viewed in the recording chamber using phase contrast (left) or fluorescent (right) microscopy; ErbB4+ (arrow) and ErbB4 - (arrowhead) neurons are marked (magnification 63×). B, Representative traces of current injection steps, showing the rheobase current (red) and one subsequent trace (black). Below each trace is the accompanying current injection protocol (50 pA steps, not to scale). C, Summary graph of normalized current threshold to evoke an AP at 20 min ( $E^{+} \mathrm{N}, n=9$; $\left.\mathrm{E}^{-} \mathrm{N}, n=5 ; \mathrm{E}^{+} \mathrm{V}, n=6 ; \mathrm{E}^{+} \mathrm{NPD}, n=6\right) ;{ }^{* *} p<0.005$ comparing $\mathrm{E}^{+} \mathrm{N}$ to $\mathrm{E}^{+} \mathrm{V}$ and $\mathrm{E}^{+} \mathrm{NPD} ; \# p<0.05$ comparing $\mathrm{E}^{+} \mathrm{N}$ to $\mathrm{E}^{-} \mathrm{N}$. $\boldsymbol{D}$, Summary graph of normalized $\mathrm{ISI}$ at 20 min averaged over all current injections $\left(\mathrm{E}^{+} \mathrm{N}, n=5 ; \mathrm{E}^{-} \mathrm{N}, n=3 ; \mathrm{E}^{+} \mathrm{V}, n=3 ; \mathrm{E}^{+} \mathrm{NPD}, n=4\right) ;{ }^{* *} p<0.005$ comparing $\mathrm{E}^{+} \mathrm{N}$ to $\mathrm{E}^{-} \mathrm{N}, \mathrm{E}^{+} \mathrm{V}$, and $\mathrm{E}^{+} \mathrm{NPD}$. Inset shows example of ErbB4 + cell firing at baseline (black) and $20 \mathrm{~min}$ (red) after NRG1 application at $700 \mathrm{pA}$ injection. Calibration: $20 \mathrm{mV}, 10 \mathrm{~s}$.

further our understanding of how this pathway functions to regulate network activity.

\section{Materials and Methods}

Hippocampal cultures and live labeling of ErbB4+ neurons Dissociated hippocampal cultures, essentially glia free, were prepared from embryonic day 19 Sprague Dawley rats of either sex as described previously (Brewer, 1995). Cells were plated $\left(5 \times 10^{4}\right.$ cells $\left./ \mathrm{ml}\right)$ on $22 \mathrm{~mm}$ coverslips and cultured for 15-21 d in Neurobasal Medium supplemented with B27 (Gibco Invitrogen). For antibody live-labeling experiments of ErbB4+ neurons, coverslips were incubated for $10 \mathrm{~min}\left(36^{\circ} \mathrm{C}\right)$ with mouse monoclonal antibody mAb77 raised against the extracellular $\mathrm{N}$ terminus of ErbB4 (Thermo Scientific; Chen et al., 1996), diluted 1:1000 in artificial CSF (ACSF; $1 \mu \mathrm{g} / \mu \mathrm{l}$ final concentration). Coverslips were transferred to ACSF with secondary goat anti-mouse antibody (diluted 1:1000) conjugated to Alexa Fluor 488 (Invitrogen) for $10 \mathrm{~min}$ and washed by transferring the coverslip into ACSF.

Drugs

The epidermal growth factor-like domain of human NRG-1 $\beta 1$ (R\&D Systems) was stabilized in $0.1 \%$ bovine serum albumin. The ErbB receptor inhibitor 4-6-(methyl-amino)-pyrido[3,4-d]pyrimidine (PD158780; Calbiochem) was dissolved in dimethyl sulfoxide. CNQX disodium salt, D-AP5, tetrodotoxin (TTx) citrate (all from Tocris Bioscience), and $\mathrm{CdCl}_{2}$ (Sigma) were dissolved in water. Picrotoxin (Tocris Bioscience) and other drugs were diluted $\geq 1000$-fold to final concentrations in ACSF.

\section{Electrophysiology}

Coverslips were transferred to a submerged recording chamber continuously perfused at $2 \mathrm{ml} / \mathrm{min}$ at $30-35^{\circ} \mathrm{C}$ with ACSF containing (in $\mathrm{mm}$ ): $124 \mathrm{NaCl}, 25 \mathrm{Na}_{2} \mathrm{HCO}_{3}, 11$ glucose, $2.5 \mathrm{KCl}, 1.3 \mathrm{MgCl}_{2}, 2.5 \mathrm{CaCl}_{2}, 1.25$ $\mathrm{NaH}_{2} \mathrm{PO}_{4}$, bubbling with carbogen. Multiclamp 700A and 700B and Axopatch 200B amplifiers equipped with Digidata 1322A or 1440 data acquisition boards and pCLAMP10 software (all from Molecular Devices) were used. Bridge balance and access resistance were monitored during recordings and experiments with $>20 \%$ change were discarded. Synaptic currents were blocked with CNQX $(10 \mu \mathrm{M})$, AP5 $(25 \mu \mathrm{M})$, and picrotoxin $(100 \mu \mathrm{M})$. NRG1 (1 nM) and PD158780 (10 $\mu \mathrm{M})$ were diluted immediately before bath application.

Current clamp. Whole-cell recordings were performed with borosilicate glass microelectrodes (3-5 M $\Omega$ ) filled with internal solution containing (in mM): $125 \mathrm{~K}$-gluconate, $20 \mathrm{KCl}, 10 \mathrm{HEPES}, 0.5 \mathrm{EGTA}, 4 \mathrm{Mg}$-ATP, 0.3 Na-GTP, 10 phosphocreatine, at $\mathrm{pH} 7.2$ adjusted with $\mathrm{KOH}$. Membrane 
A

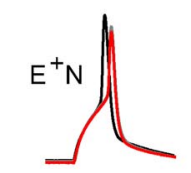

C
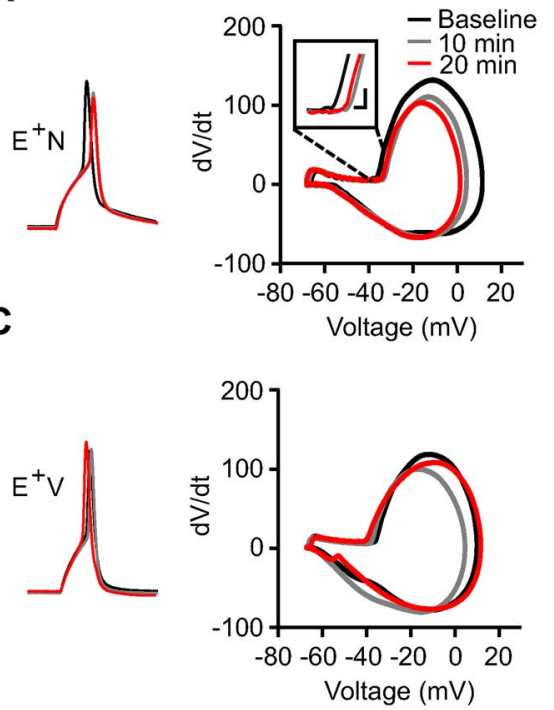

B
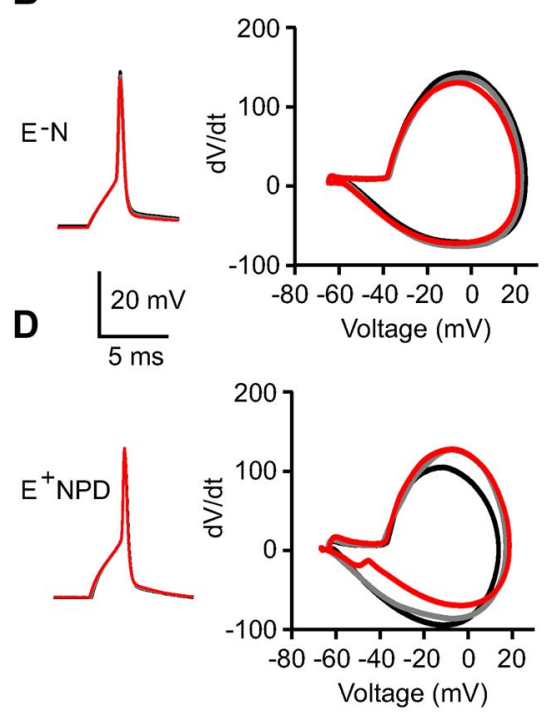

$300 \mathrm{~ms}, 20 \mathrm{mV}$ steps to $+80 \mathrm{mV}$. Activation curves were fitted to Boltzmann relationships as previously described (Yu et al., 2006).

Statistics. Data are represented as mean \pm SEM. Statistical analyses were performed using SigmaPlot. All data were analyzed with oneway ANOVA with Bonferroni-Holm's corrected post hoc tests for comparisons between groups, or paired Student's $t$ test when comparing two groups, unless otherwise noted.

\section{Results}

ErbB4-expresssing GABAergic interneurons constitute only $\sim 10 \%$ of neurons in dissociated hippocampal cultures (Longart et al., 2007). To differentiate ErbB4-positive $($ ErbB4+) interneurons from ErbB4 immunonegative (ErbB4-) neurons before recording (Fig. 1A), cultures were live-labeled with mAb77 as described previously (Fenster et al., 2012). Importantly, in initial characterization experiments, we blindly recorded from neurons first, and subsequently added mAb77, to confirm that prelabeling with low concentrations of mAb77 did not affect neuronal properties (data not shown). As previously reported (Longart et al., 2007; Fenster et al., 2012), we found no effects of mAb77 at these low concentrations. Four experimental conditions were used to determine direct NRG1/ErbB4 signaling effects on neuronal excitability: $\mathrm{E}^{+} \mathrm{N}$ : ErbB4+ interneurons treated with NRG1, $\mathrm{E}^{-} \mathrm{N}$ : ErbB4- neurons treated with NRG1, $\mathrm{E}^{+} \mathrm{V}$ : ErbB4+ interneurons treated with vehicle, and $\mathrm{E}^{+} \mathrm{NPD}$ : ErbB4+ interneurons treated with NRG1 and PD158780, a pan-ErbB antagonist.

Figure 2. NRG1 depolarizes action potential threshold. $A-D$, Representative traces of a single AP evoked from a suprathreshold current injection (left) and corresponding phase plots (dV/dt vs $V_{m}$; right) measured at baseline (black), and following $10 \mathrm{~min}$ (gray) and $20 \mathrm{~min}$ (red) of treatment. Inset magnifies threshold in $\mathrm{E}^{+} \mathrm{N}$ phase plot. Calibration: $2 \mathrm{mV}, 10 \mathrm{mV} / \mathrm{s}$. E, Summary graph for normalized AP threshold, as determined by $\mathrm{d}^{3} \mathrm{~V} / \mathrm{dt}^{3}$ plots, at $20 \min \left(\mathrm{E}^{+} \mathrm{N}, n=5 ; \mathrm{E}^{-} \mathrm{N}, n=5 ; \mathrm{E}^{+} \mathrm{V}, n=5 ; \mathrm{E}^{+} \mathrm{NPD}, n=6\right)$. ${ }^{* *} p<0.005$ comparing $\mathrm{E}^{+} \mathrm{N}$ to $\mathrm{E}^{+} \mathrm{NPD}$; ${ }^{\#} p<0.05$ comparing $\mathrm{E}^{+} \mathrm{N}$ to $\mathrm{E}^{-} \mathrm{N}$ and $\mathrm{E}^{+} \mathrm{V}$.

potential was set at $-65 \mathrm{mV}$ before injection protocols and input resistance was calculated from steady-state voltage in response to current injections. Rheobase current was measured with a series of $500 \mathrm{~ms}, 50 \mathrm{pA}$ hyperpolarizing and depolarizing current steps $(-150$ to $+900 \mathrm{pA})$, and defined as the smallest current injection needed to elicit an AP. To measure AP waveform, a suprathreshold depolarizing current was injected for $5 \mathrm{~ms}$. All baseline APs overshot $0 \mathrm{mV}$. Absolute AP amplitude was measured from onset to peak. AP duration was measured at the halfmaximal amplitude. Threshold voltage was calculated from the first peak on $\mathrm{d}^{3} \mathrm{~V} / \mathrm{dt}^{3}$ versus $V_{\mathrm{m}}$ plots (Henze and Buzsaki, 2001). Data were normalized to their own baseline values.

Voltage clamp. To measure $\mathrm{Na}_{\mathrm{v}}$ channel currents, pipettes were coated with Sylgard to reduce capacitive transients and filled with internal solution containing (in mM): $130 \mathrm{CsCH}_{3} \mathrm{SO}_{3}, 8 \mathrm{NaCl}, 10$ HEPES, 0.5 EGTA, $4 \mathrm{Mg}$-ATP, $0.3 \mathrm{Na}$-GTP, 10 phosphocreatine, at $\mathrm{pH} 7.2$ adjusted with $\mathrm{CsOH}$. TEA ( $10 \mathrm{~mm})$ and $5 \mathrm{~mm} 4 \mathrm{AP}$ were supplemented in this solution to reduce $\mathrm{K}^{+}$currents and avoid effects of $\mathrm{Cl}^{-}$conductance (modified from Milescu et al., 2010b). Pipette and whole-cell capacitance as well as series resistance were compensated by $>85 \%$. Somatic $\mathrm{Na}^{+}$current was evoked with a $5 \mathrm{~ms}$ depolarizing pulse $(-20 \mathrm{mV})$, to induce the activation of uncontrolled axial $\mathrm{Na}^{+}$ currents, followed by a $0.5 \mathrm{~ms}$ step to $-65 \mathrm{mV}$ and $5 \mathrm{mV}$ steps from -80 to $+60 \mathrm{mV}$ (Milescu et al., 2010a); cells were held at $-80 \mathrm{mV}$. All $\mathrm{Na}^{+}$currents were confirmed with TTx $(1 \mu \mathrm{M}) . \mathrm{K}_{\mathrm{v}}$ channel currents were measured with the K-gluconate-based internal solution in the presence of TTx $(1 \mu \mathrm{M})$, holding the cell at $-80 \mathrm{mV}$, and applying

\section{NRG1 decreases ErbB4+ interneuron excitability}

We initially assessed the effects of acute NRG1 application on neuronal rheobase current, firing pattern, and interspike interval (ISI) using whole-cell current-clamp recordings. Figure $1 B$ shows neuronal responses to the rheobase current step (red) and an additional step that elicited multiple APs (black) to confirm neuron viability. As shown in the current steps below the raw traces (Fig. 1B), NRG1 application significantly increased the rheobase current in ErbB4+ neurons, but not ErbB4- neurons or ErbB4+ cells also treated with PD158780 (Fig. 1C). Importantly, input resistance was not affected by NRG1 application (data not shown; $p=0.15$ ). These data reveal that NRG1/ErbB4 signaling directly affects interneuron intrinsic excitability. The effects of NRG1 on ISI were analyzed during periods of repetitive firing. We found that NRG1 increased the ISI, and reduced firing frequency, in ErbB4+ neurons (Fig. 1D, inset), while these parameters were not affected in control conditions.

\section{AP threshold depolarizes with NRG1 application}

Changes in neuronal excitability are due to many factors including AP threshold and waveform (Rutecki, 1992). To isolate intrinsic AP waveform characteristics, we evoked a single 
AP with a brief suprathreshold current injection. As shown in representative traces and corresponding $\mathrm{dV} / \mathrm{dt}$ phase plots (Fig. 2A-D), NRG1 depolarized the AP threshold in ErbB4+ neurons. Notably, in two of seven $\mathrm{E}^{+} \mathrm{N}$ experiments, 20 min of NRG1 application depolarized the AP threshold such that no AP was evoked. Although these cells were not considered for AP threshold or duration to avoid artificially skewing the data, they support a substantial shift in threshold. As summarized in Figure $2 E$, firing threshold was significantly more depolarized in ErbB4+ interneurons with $\mathrm{NRG1}$ application $\left(\mathrm{E}^{+} \mathrm{N}\right.$ : $88.4 \pm 1.2 \% ; \mathrm{E}^{-} \mathrm{N}: 101.4 \pm 3 \% ; \mathrm{E}^{+} \mathrm{V}$ : $102.8 \pm 5.2 \%$; $\left.E^{+} \mathrm{NPD}: 106 \pm 3.1 \%\right)$. In addition to these changes, NRG1 application decreased AP amplitude in ErbB4+ interneurons, while minor changes were seen with vehicle or in ErbB4- neurons (Fig. 2A-D). On average, AP amplitude tended to decrease with NRG1 application $\left(\mathrm{E}^{+} \mathrm{N}: 82.7 \pm\right.$ $7.7 \%, n=7 ; p=0.06$ ), while this trend was not observed in control conditions $\left(\mathrm{E}^{-} \mathrm{N}: 97.3 \pm 0.8 \%, \mathrm{E}^{+} \mathrm{V}: 99.1 \pm 2.6 \%\right.$, $\mathrm{E}^{+} \mathrm{NPD}: 99.8 \pm 2.7 \%, n=5-6 ; p=$ 0.7 ). AP duration was not affected (data not shown), a parameter attributed to $\mathrm{K}_{\mathrm{v}}$ channel activity (Jaffe et al., 2011).

In some experiments, PD158780 appeared to decrease threshold and increase AP amplitude (Fig. 2D), suggesting a potential role for endogenous NRG1 activity as previously reported (Kwon et al., 2005; Kaphzan et al., 2011; Shamir et al., 2012), although these effects were not significant.

Our results show that NRG1 reduces the intrinsic excitability and depolarizes AP threshold in ErbB4+ interneurons. These effects are specific to ErbB4+ interneurons because they are absent in ErbB4- cells and ErbB4+ neurons perfused with vehicle or PD158780. Having shown NRG1 specificity for ErbB4+ interneurons, we compared NRG1 to vehicle application for the remaining experiments.

\section{Acute NRG1 treatment dramatically decreases sodium currents}

We sought to determine whether NRG1 affected $\mathrm{Na}_{\mathrm{v}}$ channels, based on their pivotal role in AP generation and peak. We measured $\mathrm{Na}_{\mathrm{v}}$ channel current in whole-cell voltage-clamp mode using a protocol (Fig. 3, inset) to isolate somatic $\mathrm{Na}^{+}$currents (Milescu et al., 2010a), in the presence and absence of the voltage-gated calcium channel blocker, $\mathrm{CdCl}_{2}(0.2 \mathrm{mM})$. Data were pooled as no differences were seen between these groups. Figure $3 A$ shows representative traces from an ErbB4+ interneuron where NRG1 application dramatically decreased the total, TTx-sensitive $\mathrm{Na}^{+}$current. On average, NRG1 decreased the maximum $\mathrm{Na}^{+}$current density (baseline:

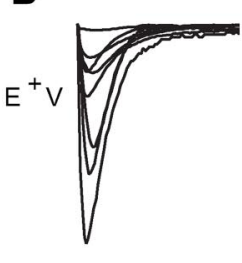

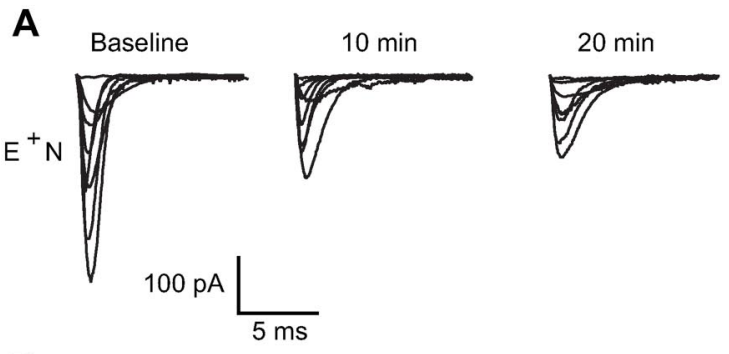
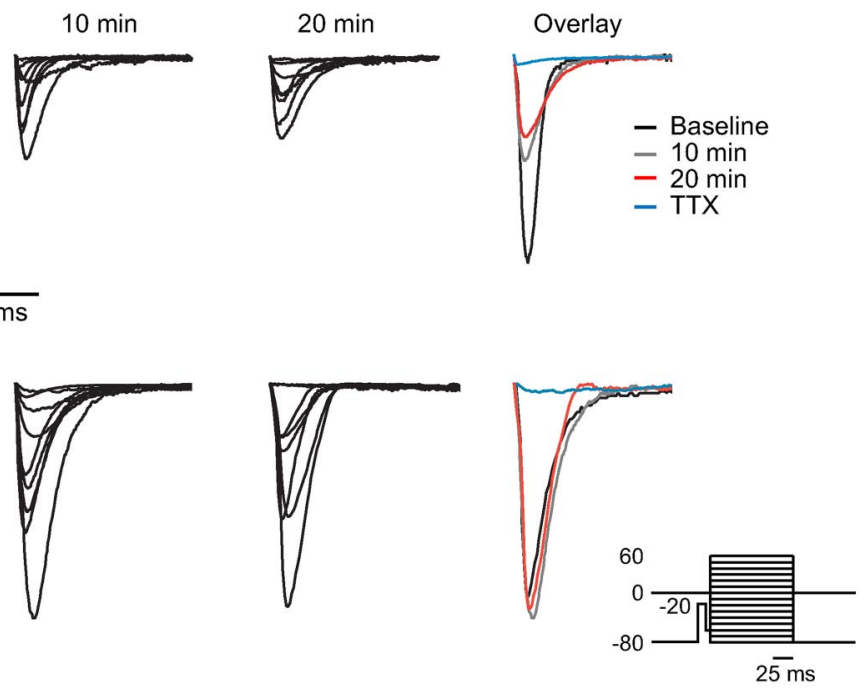

C

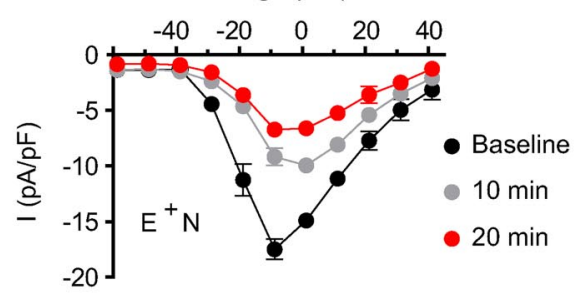

E

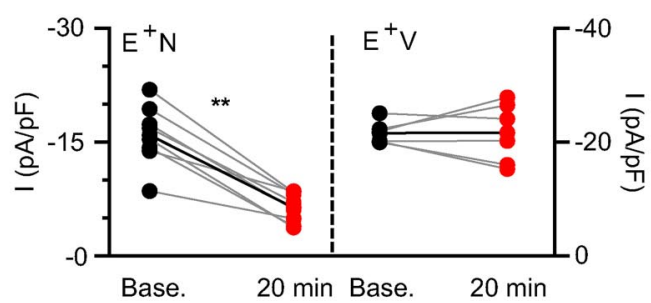

Figure 3. NRG1 application dramatically reduces voltage-gated sodium channel currents. $\boldsymbol{A}, \boldsymbol{B}$, Representative traces of $\mathrm{Na}_{\mathrm{v}}$ currents from an ErbB4+ interneuron before (baseline) and after NRG1 $(\boldsymbol{A})$ or vehicle $(\boldsymbol{B})$ application for 10 and 20 min. Far right shows overlaid maximum $\mathrm{Na}^{+}$currents. Inset shows voltage-clamp protocol used to evoke somatic $\mathrm{Na}^{+}$channel current. $\boldsymbol{C}, \boldsymbol{D}$, veraged I/V relationship for $\mathrm{Na}_{v}$ channel activation showing the NRG1-specific decrease in $\mathrm{Na}^{+}$channel density $(n=8 ; \mathrm{C})$ min are plotted with their own baseline (gray lines). Average response depicted with black line. $F$, Averaged normalized maximum current density from $\mathrm{E}^{+} \mathrm{N}$ and $\mathrm{E}^{+} \mathrm{V}$ cells. ${ }^{*} \mathrm{p}<0.05$ comparing $\mathrm{E}^{+} \mathrm{N} 10$ min to $\mathrm{E}^{+} \mathrm{V} 10$ min; ${ }^{* *} p<0.005$ comparing $\mathrm{E}^{+} \mathrm{N} 20$ min to $\mathrm{E}^{+} \mathrm{V} 20$ min, two-way ANOVA.

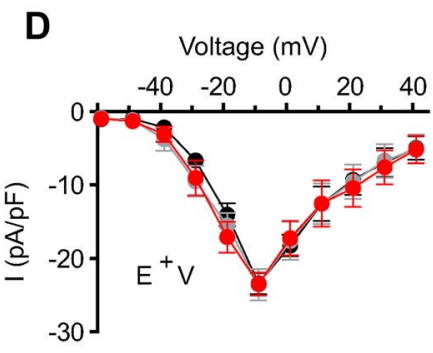

$\mathbf{F}$

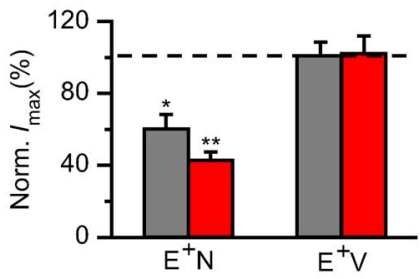


A
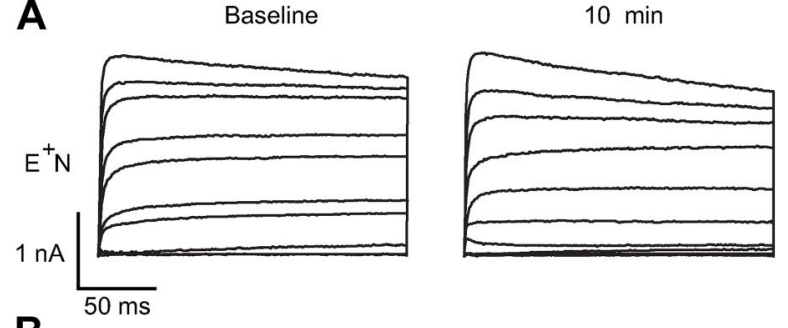

B
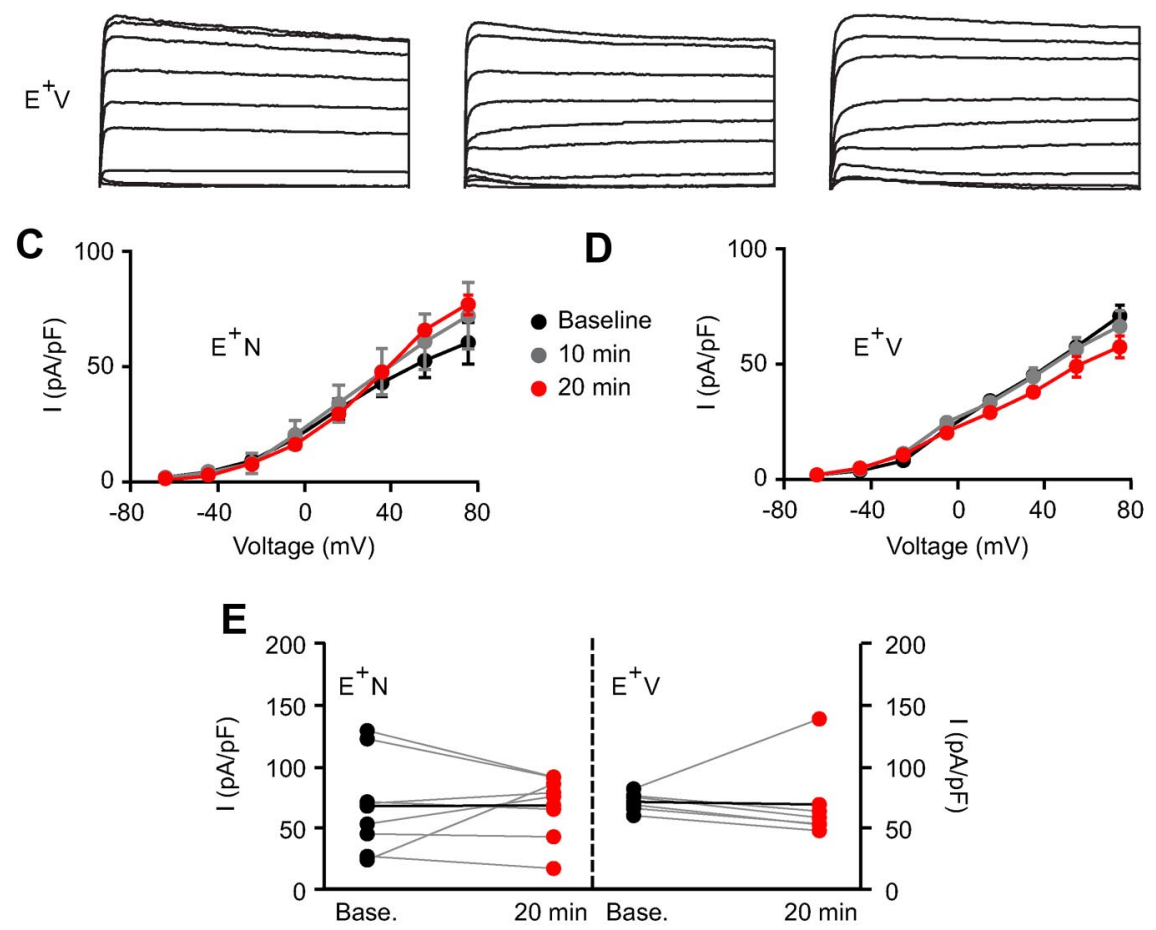

Figure 4. NRG1 does not affect potassium currents. $\boldsymbol{A}, \boldsymbol{B}$, Representative traces of $\mathrm{K}_{v}$ channel currents from ErbB4+ interneurons with NRG1 $(\boldsymbol{A})$ or vehicle application $(\boldsymbol{B})$ for baseline, $10 \mathrm{~min}$, and $20 \mathrm{~min}$ recordings. $\boldsymbol{C}, \boldsymbol{D}$, Averaged $I / V$ relationship for $\mathrm{K}^{+}$ current density showing a lack of effects with $\operatorname{NRG1~}(n=8 ; \boldsymbol{C})$ or vehicle $(n=6 ; \boldsymbol{D})$. $\boldsymbol{E}$, Individual $\mathrm{K}^{+}$channel current responses to NRG1 (left) or vehicle application (right) at 20 min are plotted with their own baseline (gray lines). Average response depicted with a black line.

Because $\mathrm{K}_{\mathrm{v}}$ channels are also active at near-threshold voltages and participate in AP waveform and neuronal excitability, we assessed whether NRG1 also affected $\mathrm{K}_{\mathrm{v}}$ currents. As shown in Figure $4, A$ and $B, K_{v}$ channels were activated with voltage steps in the presence of TTx. In contrast to $\mathrm{Na}^{+}$currents, a 20 min application of NRG1 or vehicle did not affect $\mathrm{K}^{+}$channel current density (Fig. $4 C$ ) or normalized maximum $\mathrm{K}^{+}$currents $\left(\mathrm{E}^{+} \mathrm{N}\right.$ : $67.6 \pm 17.4$ to $66.8 \pm 9.3 \mathrm{pA} ; \mathrm{E}^{+} \mathrm{V}: 70.6 \pm 3.5$ to $68.4 \pm 15.4 \mathrm{pA}$; $p=0.2$; Fig. $4 E)$.

Furthermore, using whole-cell conductance to plot the AP's net ionic current $\left(-C^{\star} \mathrm{dV} / \mathrm{dt}\right.$ vs $t$ ) (Carter and Bean, 2009), we saw a decrease in $\mathrm{Na}_{v}$ current and no changes to $K_{v}$ current (data not shown), consistent with our voltage-clamp experiments. These data demonstrate that NRG1 affects $\mathrm{Na}_{\mathrm{v}}$ channels to increase AP threshold and decrease ErbB4+ interneuron excitability.

\section{Discussion}

Experiments in dissociated cultures are extremely valuable because they are one of the few approaches to study how ErbB4 activation modulates the intrinsic properties of GABAergic neurons, in absence of afferents that release neuromodulators. By recording from pharmacologically isolated and labeled ErbB4+ interneurons in dissociated hippocampal cultures, we determined the direct effects of NRG1/ ErbB4 signaling. We show that NRG1 reduces the excitability of dissociated ErbB4 + interneurons, depolarizes the AP threshold, and decreases maximum $\mathrm{Na}_{\mathrm{v}}$ channel somatic current, without affecting $\mathrm{K}^{+}$currents or passive membrane properties. These results identify the direct effects of NRG1/ErbB4 signaling as changes were not seen with PD158780 or in ErbB4- neurons.

Depolarized AP threshold and decreased AP amplitude have been correlated to decreased whole-cell $\mathrm{Na}_{\mathrm{v}}$ current and excitability (Zhan et al., 2007). Our results also support an interaction between altered $\mathrm{Na}^{+}$channel current, AP waveform, and neuronal excitability. Although further studies are needed, it is plausible that ErbB4 receptor activation of Src family tyrosine kinases (Pitcher et al., 2011) may selectively reduce $\mathrm{Na}_{\mathrm{v}}$ channel activity (Ahn et al., 2007). Furthermore, NRG1 may regulate $\mathrm{Na}_{\mathrm{v}}$ channel surface distribution and/or trafficking, as reported for $\alpha 7$-containing acetylcholine receptors in interneurons (Chang and Fischbach, 2006).

AP waveform, duration, and firing frequency can also be affected by $\mathrm{K}_{\mathrm{v}}$ channel currents (Lawrence et al., 2006; Jaffe et al., 2011). Although chronic or long-term NRG1 application was reported to regulate $\mathrm{Ca}^{2+}$-activated $\mathrm{K}^{+}$channel surface expression in parasympathetic ganglia (Chae et al., 2005), we failed to observe an effect of acute NRG1 treatment on either macroscopic $\mathrm{K}^{+}$current or AP duration. While this work was in progress, acute NRG1 application in cortical slices was reported to increase the intrinsic excitability of $\mathrm{PV}+$ interneurons by decreasing $\mathrm{AP}$ threshold via $\mathrm{K}_{\mathrm{v}} 1.1$ channel blockade (Li et al., 2012). These findings, although they initially may appear disparate, may be due to several experimental differences. (1) Importantly, we assessed NRG1 effects on both $\mathrm{Na}^{+}$and $\mathrm{K}^{+}$currents, while Li et al. (2012) did not investigate NRG1-mediated changes to $\mathrm{Na}_{\mathrm{v}}$ channels. (2) Our experimental conditions in dissociated hippocampal cultures are devoid of afferents, whereas the previous study was conducted in slices where NRG1-mediated release of dopamine or other neuromodulators may affect $\mathrm{K}_{\mathrm{v}}$ channels and increase excitability (Govindaiah et al., 2010). (3) The former study was restricted to $\mathrm{PV}+$ neurons, whereas we recorded from identified ErbB4+ interneurons that encompass a heterogeneous population of GABAergic neurons (Neddens and Buonanno, 2010). Comparison of ErbB4 effects in cultured versus in vivo adult neurons has limitations because dissociated neurons are at early maturation stages that fail to express high levels of biochemical markers typical of mature GABAergic subtypes. (4) Our study 
was performed in the hippocampus, while the prior study was primarily performed in cortex. (5) We showed that interneuron excitability is directly affected by ErbB4 activation because neurons expressing receptor, but not those devoid of ErbB4, responded to NRG1; the Li et al. (2012) study did not analyze non-ErbB4-expressing GABAergic interneurons. When attempting to compare these two studies, it is important to consider that an initial reduction of ErbB4+ GABAergic neuron excitability in response to NRG1 could affect dopamine levels (Kwon et al., 2008 ) and subsequently modify neuronal excitability. Therefore, the results obtained in these two studies are not directly comparable; rather, they may identify direct and/or indirect effects of NRG1 signaling or may also differ due to the other aforementioned experimental conditions.

We have shown that NRG1 directly reduces the excitability of ErbB4+ interneurons and depolarizes the AP threshold by notably decreasing $\mathrm{Na}_{\mathrm{v}}$ currents; we cannot exclude the possibility that the small change in $V_{0.5}$ could contribute to these effects. Because increased inhibitory drive onto pyramidal neurons results from acute NRG1 application in hippocampal slices (Woo et al., 2007), for the aforementioned reasons, it will be important to determine how this NRG1-mediated decrease in ErbB4+ interneuron firing plays a role in hippocampal network activity. In addition to indirect effects of NRG1 on neuromodulators, our data are also consistent with a NRG1/ ErbB4-mediated disinhibition of other interneurons, resulting in increased GABA release onto pyramidal neurons. Studies focusing on how NRG/ErbB4 signaling affects the excitability of hippocampal PV+ and cholecystokininexpressing basket cells will be exceptionally interesting; these neurons modulate gamma oscillations (Holderith et al., 2011), a form of network activity that is regulated by NRG1 (Fisahn et al., 2009) and is altered in schizophrenia and other psychiatric disorders (Gonzalez-Burgos et al., 2010).

\section{References}

Ahn M, Beacham D, Westenbroek RE, Scheuer T, Catterall WA (2007) Regulation of $\mathrm{Na}(\mathrm{v}) 1.2$ channels by brain-derived neurotrophic factor, TrkB, and associated Fyn kinase. J Neurosci 27:11533-11542. CrossRef Medline

Bean BP (2007) The action potential in mammalian central neurons. Nat Rev Neurosci 8:451-465. CrossRef Medline

Bjarnadottir M, Misner DL, Haverfield-Gross S, Bruun S, Helgason VG, Stefansson H, Sigmundsson A, Firth DR, Nielsen B, Stefansdottir R, Novak TJ, Stefansson K, Gurney ME, Andresson T (2007) Neuregulin1 (NRG1) signaling through Fyn modulates NMDA receptor phosphorylation: differential synaptic function in NRG1 ${ }^{+/-}$knock-outs compared with wild-type mice. J Neurosci 27:4519-4529. CrossRef Medline

Brewer GJ (1995) Serum-free B27/neurobasal medium supports differentiated growth of neurons from the striatum, substantia nigra, septum, cerebral cortex, cerebellum, and dentate gyrus. J Neurosci Res 42:674-683. CrossRef Medline

Buonanno A (2010) The neuregulin signaling pathway and schizophrenia: from genes to synapses and neural circuits. Brain Res Bull 83:122131. CrossRef Medline

Carter BC, Bean BP (2009) Sodium entry during action potentials of mammalian neurons: incomplete inactivation and reduced metabolic efficiency in fast-spiking neurons. Neuron 64:898-909. CrossRef Medline

Chae KS, Martin-Caraballo M, Anderson M, Dryer SE (2005) Akt activation is necessary for growth factor-induced trafficking of functional KCa channels in developing parasympathetic neurons. J Neurophysiol 93:11741182. CrossRef Medline

Chang Q, Fischbach GD (2006) An acute effect of neuregulin 1 beta to suppress alpha 7-containing nicotinic acetylcholine receptors in hippocampal interneurons. J Neurosci 26:11295-11303. CrossRef Medline

Chen X, Levkowitz G, Tzahar E, Karunagaran D, Lavi S, Ben-Baruch N,
Leitner O, Ratzkin BJ, Bacus SS, Yarden Y (1996) An immunological approach reveals biological differences between the two NDF/heregulin receptors, ErbB-3 and ErbB-4. J Biol Chem 271:7620-7629. CrossRef Medline

Chen YJ, Zhang M, Yin DM, Wen L, Ting A, Wang P, Lu YS, Zhu XH, Li SJ, Wu CY, Wang XM, Lai C, Xiong WC, Mei L, Gao TM (2010) ErbB4 in parvalbumin-positive interneurons is critical for neuregulin 1 regulation of long-term potentiation. Proc Natl Acad Sci U S A 107: 21818-21823. CrossRef Medline

Fenster C, Vullhorst D, Buonanno A (2012) Acute neuregulin-1 signaling influences AMPA receptor mediated responses in cultured cerebellar granule neurons. Brain Res Bull 87:21-29. CrossRef Medline

Fisahn A, Neddens J, Yan L, Buonanno A (2009) Neuregulin-1 modulates hippocampal gamma oscillations: implications for schizophrenia. Cereb Cortex 19:612-618. CrossRef Medline

Gonzalez-Burgos G, Hashimoto T, Lewis DA (2010) Alterations of cortical GABA neurons and network oscillations in schizophrenia. Curr Psychiatry Rep 12:335-344. CrossRef Medline

Govindaiah G, Wang Y, Cox CL (2010) Dopamine enhances the excitability of somatosensory thalamocortical neurons. Neuroscience 170: 981-991. CrossRef Medline

Harrison PJ, Weinberger DR (2005) Schizophrenia genes, gene expression, and neuropathology: on the matter of their convergence. Mol Psychiatry 10:40-68. CrossRef Medline

Henze DA, Buzsaki G (2001) Action potential threshold of hippocampal pyramidal cells in vivo is increased by recent spiking activity. Neuroscience 105:121-130. CrossRef Medline

Holderith N, Németh B, Papp OI, Veres JM, Nagy GA, Hájos N (2011) Cannabinoids attenuate hippocampal gamma oscillations by suppressing excitatory synaptic input onto CA3 pyramidal neurons and fast spiking basket cells. J Physiol 589:4921-4934. CrossRef Medline

Huang YZ, Won S, Ali DW, Wang Q, Tanowitz M, Du QS, Pelkey KA, Yang DJ, Xiong WC, Salter MW, Mei L (2000) Regulation of neuregulin signaling by PSD-95 interacting with ErbB4 at CNS synapses. Neuron 26: 443-455. CrossRef Medline

Jaffe DB, Wang B, Brenner R (2011) Shaping of action potentials by type I and type II large-conductance $\mathrm{Ca}(2)+$-activated $\mathrm{K}+$ channels. Neuroscience 192:205-218. CrossRef Medline

Kaphzan H, Buffington SA, Jung JI, Rasband MN, Klann E (2011) Alterations in intrinsic membrane properties and the axon initial segment in a mouse model of Angelman syndrome. J Neurosci 31:1763717648. CrossRef Medline

Kwon OB, Longart M, Vullhorst D, Hoffman DA, Buonanno A (2005) Neuregulin-1 reverses long-term potentiation at CA1 hippocampal synapses. J Neurosci 25:9378-9383. CrossRef Medline

Kwon OB, Paredes D, Gonzalez CM, Neddens J, Hernandez L, Vullhorst D, Buonanno A (2008) Neuregulin-1 regulates LTP at CA1 hippocampal synapses through activation of dopamine D4 receptors. Proc Natl Acad Sci U S A 105:15587-15592. CrossRef Medline

Lawrence JJ, Saraga F, Churchill JF, Statland JM, Travis KE, Skinner FK, McBain CJ (2006) Somatodendritic Kv7/KCNQ/M channels control interspike interval in hippocampal interneurons. J Neurosci 26:1232512338. CrossRef Medline

Li KX, Lu YM, Xu ZH, Zhang J, Zhu JM, Zhang JM, Cao SX, Chen XJ, Chen Z, Luo JH, Duan S, Li XM (2012) Neuregulin 1 regulates excitability of fast-spiking neurons through Kv1.1 and acts in epilepsy. Nat Neurosci 15:267-273. CrossRef Medline

Longart M, Chatani-Hinze M, Gonzalez CM, Vullhorst D, Buonanno A (2007) Regulation of ErbB-4 endocytosis by neuregulin in GABAergic hippocampal interneurons. Brain Res Bull 73:210-219. CrossRef Medline

Matzner O, Devor M (1992) Na+ conductance and the threshold for repetitive neuronal firing. Brain Res 597:92-98. CrossRef Medline

Mei L, Xiong WC (2008) Neuregulin 1 in neural development, synaptic plasticity and schizophrenia. Nat Rev Neurosci 9:437-452. CrossRef Medline

Milescu LS, Bean BP, Smith JC (2010a) Isolation of somatic Na+ currents by selective inactivation of axonal channels with a voltage prepulse. J Neurosci 30:7740-7748. CrossRef Medline

Milescu LS, Yamanishi T, Ptak K, Smith JC (2010b) Kinetic properties and functional dynamics of sodium channels during repetitive spiking in a slow pacemaker neuron. J Neurosci 30:12113-12127. CrossRef Medline Neddens J, Buonanno A (2010) Selective populations of hippocampal in- 
terneurons

express ErbB4 and their number and distribution is altered in ErbB4 knockout mice. Hippocampus 20:724-744. CrossRef Medline

Neddens J, Fish KN, Tricoire L, Vullhorst D, Shamir A, Chung W, Lewis DA, McBain CJ, Buonanno A (2011) Conserved interneuron-specific ErbB4 expression in frontal cortex of rodents, monkeys, and humans: implications for schizophrenia. Biol Psychiatry 70:636-645. CrossRef Medline

Pitcher GM, Kalia LV, Ng D, Goodfellow NM, Yee KT, Lambe EK, Salter MW (2011) Schizophrenia susceptibility pathway neuregulin 1-ErbB4 suppresses Src upregulation of NMDA receptors. Nat Med 17:470-478. CrossRef Medline

Rutecki PA (1992) Neuronal excitability: voltage-dependent currents and synaptic transmission. J Clin Neurophysiol 9:195-211. CrossRef Medline

Shamir A, Kwon OB, Karavanova I, Vullhorst D, Leiva-Salcedo E, Janssen MJ, Buonanno A (2012) The importance of the NRG-1/ErbB4 pathway for synaptic plasticity and behaviors associated with psychiatric disorders. J Neurosci 32:2988-2997. CrossRef Medline

Vullhorst D, Neddens J, Karavanova I, Tricoire L, Petralia RS, McBain CJ,
Buonanno A (2009) Selective expression of ErbB4 in interneurons, but not pyramidal cells, of the rodent hippocampus. J Neurosci 29:1225512264. CrossRef Medline

Woo RS, Li XM, Tao Y, Carpenter-Hyland E, Huang YZ, Weber J, Neiswender H, Dong XP, Wu J, Gassmann M, Lai C, Xiong WC, Gao TM, Mei L (2007) Neuregulin-1 enhances depolarization-induced GABA release. Neuron 54:599-610. CrossRef Medline

Yu FH, Mantegazza M, Westenbroek RE, Robbins CA, Kalume F, Burton KA, Spain WJ, McKnight GS, Scheuer T, Catterall WA (2006) Reduced sodium current in GABAergic interneurons in a mouse model of severe myoclonic epilepsy in infancy. Nat Neurosci 9:1142-1149. CrossRef Medline

Zhan RZ, Nadler JV, Schwartz-Bloom RD (2007) Impaired firing and sodium channel function in CA1 hippocampal interneurons after transient cerebral ischemia. J Cereb Blood Flow Metab 27:1444-1452. CrossRef Medline 